\title{
FACTORS THAT INFLUENCE THE OUTCOME OF INFORMATION TECHNOLOGY PROJECTS IN SOUTH AFRICA: AN EMPIRICAL INVESTIGATION
}

\author{
Dr. Carl Marnewick: Department of Business Information Technology, University of \\ Johannesburg
}

\author{
Prof Les Labuschagne: Department of Business Information Technology, University of \\ Johannesburg
}

\begin{abstract}
Purpose: In developing countries such as South Africa, many organisations are reliant on information and communication technology (ICT) to provide accurate, relevant and timely information. For organisations to obtain and sustain a competitive advantage, ICT systems are constantly implemented, upgraded, modified or replaced. These initiatives are often managed as projects.
\end{abstract}

While there is an increasing amount of both financial resources and effort being spent on ICT, these projects are not always delivered within the predetermined project constraints. This implies additional time to complete, as well as additional costs, as resources are not released in time to participate in other projects. It is therefore important to understand the factors that influence the outcome of South African ICT projects relative to their original constraints.

Problem Investigated: The goal of this article is to determine the factors that influence South African ICT projects, taking into consideration the fact that most current published research on this topic was done within the context of a developed country such as the USA and Europe.

Design and/or methodology: The outcomes of ICT projects in South Africa as well as the factors that influence them were determined through an extensive survey. An analysis was done on the factors together with a correlation between the main factors contributing to project outcomes. The purpose of this was to establish if a factor's presence or absence influenced the eventual outcome.

Findings: The factors that contribute to a successful outcome are often outside the direct control of the project manager and tend to be complex in nature. One factor that does stand out is that the alignment of projects with business objectives influences their perceived success.

Originality/Value: The benefits of this article are that it firstly provides a South African perspective of current ICT project management practices, and secondly, it highlights factors that influence project outcome. Organisations can use this information to improve their current practices.

Conclusion: The value of the research results presented in this paper lies in the realisation that project success is not just determined by adherence to best practices or formal processes, but requires an environment and context conducive to business success.

Keywords: Information technology, projects, project management, project outcome, project success, project failure, empirical research, survey, South Africa

\section{INTRODUCTION}

In the last few years, the project management discipline has matured through the publication of several standards [Ahlemann, Teuteberg \& Vogelsang, in press; Crawford, Pollack \& England, 2007], best practices [Crawford \& Pollack, 2007], research articles [Marnewick \& Labuschagne, 2008; Sewchurran \& Barron, 2008] and significant growth in its community of professional practitioners [Smith, 2003; Leyborne, 2007]. From this, it may be concluded that today, the majority of projects are completed successfully. However, literature suggests that this is not the case, especially in the information and communication technology (ICT) environment [Hyväri, 2006; Rubinstein, 2007; Pellegrinelli, Partington, Hemingway, Mohdzain \& Shah, 2007].

According to the 2006 Chaos report [Rubinstein, 2007], only 35\% of ICT projects are completed successfully, with $19 \%$ being outright failures and $46 \%$ being challenged. The Chaos report defines a challenged project as completed and operational, but over budget and/or over the time estimate and/or with fewer features and functions than initially specified [McPherson, n.d.]. This definition is 
based on the triple constraint of projects [Peterson, 2007; Schwalbe, 2007:8] and differs from what others consider the criteria to be for measuring project outcome [Agarwal \& Rathod, 2006; Muller \& Turner, 2007]. The report further shows that there is an inverse correlation between the size of the project and its outcome [Ives, 2005]. The larger the project, the lower the probability of success and vice versa.

The above results are obtained from surveys conducted predominantly among US-based organisations. Similar studies have been done for other developed countries as well [O'Leary \& Williams, 2008; Thomas \& Fernandez, in press]. Recent statistics on South African success rates could not be found. In 2003, the Prosperus report [Sonnekus \& Labuschagne, 2003; Sonnekus \& Labuschagne, 2004] showed the success rate of ICT projects in South Africa to be $43 \%$, with $35 \%$ being challenged and $22 \%$ failing.

This article provides the results of a research project that set out to answer three questions within the South African context:

- What is the outcome of ICT projects and how does that compare to the 2003 Prosperus report?

- What is the correlation between the size of the project and project outcome?

- What factors influence the outcome of a project and what is the correlation between those factors?

The article is divided into three main sections. The first describes the research methodology and design that were followed in conducting the research. The second section focuses on the analysis and interpretation of the results in relation to the three research questions stated above. The third section provides some recommendations to ensure continuous improvement in project success.

\section{RESEARCH METHODOLOGY AND DESIGN}

Cresswell [2003:120] defines research as "a set of interrelated constructs (variables), definitions, and propositions that presents a systematic view of phenomena by specifying relations among variables, with the purpose of explaining natural phenomena". This research observes the current practices in industry through a survey and attempts to provide some explanation as to the observed phenomena. The research design as a strategic framework provides an explicit plan of action which includes the techniques for data collection, analysis and reporting [Hart, 1989; Blanche \& Durrheim, 2004; Emrouznejad, Parker \& Tavares, 2008].

The research type used is exploratory in nature. Devlin [2006] suggests that this approach has the goal of formulating problems more precisely, obtaining insight and forming a hypothesis. This type of research is usually small scale and undertaken to define the exact nature of the problem with a view to gaining a better understanding of the environment within which the problem exists.

This research is a longitudinal study and compares the results of the Prosperus 2003 report with the current findings. The intention is that this research be repeated every second year to determine trends and influence the outcome of ICT projects in the future.

\section{Quantitative Research Approach}

The research approach selected was quantitative as project management issues are investigated in a large population using predetermined categories so that broad and general comparisons can be made [Patton, 2002; Creswell, 2003; Blanche \& Durrheim, 2004]. Another reason is that numbers can be analysed using descriptive and inferential statistics [Bless \& Higson-Smith, 2004; So \& Leung, 2004].

\section{Profile of the Respondents and Setting}

Two hundred and twenty respondents, representing different types of industries in South Africa, participated in the survey. There were 44 females, 155 males and 22 respondents who did not indicate their gender. The majority $(68.6 \%)$ of the respondents were between the ages of 30 and 50 , and 13 did not indicate their age. Participants from the various organisations presented a random 
sample, which was important to ensure that they were representative [Page \& Meyer, 2000; Blanche \& Durrheim, 2004].

\section{Data Collection Methods}

Data was collected using a structured questionnaire with 155 items placed under 23 questions. The questionnaire was distributed to over 800 people and a total of 221 responses were received. Fifteen questionnaires were removed as these were incomplete or inconsistent, leaving 206 usable responses from 10 industry sectors.

The questionnaire was hosted electronically on a website and invitations to participate were distributed via e-mail, personal invitation and a South African project management magazine. To secure as many responses from as many different industry sectors as possible, two research assistants followed up with invitees and collected data via e-mail [Devlin, 2006:131]. Senior students were also utilised in collecting responses from different organisations.

\section{ANALYSIS OF DATA}

The data collected through the questionnaire was processed and analysed by Statkon, an independent enterprise operated by the Statistics Department at the University of Johannesburg, specialising in statistical analysis. SPSS [Armstrong \& Everett, 1990; Hinton, Brownlow \& McMurray, 2004], a statistical analysis software package, was used.

The following types of analysis and statistical tests were performed on the data [Leeper, n.d.]:

- Reliability analysis - allows the researcher to study the properties of measurement scales and the items that comprise the scales

- One way ANOVA - used to test the hypothesis that several means are equal, frequent and descriptive

- T-test - tests the difference of means between two groups defined by a missing indicator variable for each of the other variables.

The mean, variance and standard deviations were devised from the data as they formed the basis for inferential statistical procedures [Blanche \& Durrheim, 2004].

\section{The Assessment of Trustworthiness}

Reliability is concerned with the consistency of measures. Equivalent-form reliability, similar to the test-retest method and item analysis, was used for judging the reliability of the research design [Bless \& Higson-Smith, 2004:179].

To ensure the validity of data, content validity, face validity and construct validity were used. Triangulation and various sources of evidence enhanced the construct validity of this study. This research is characterised by the use of different data sources (10 industry sectors), improved content and known theory or models such as the PMBoK® guide [PMI, 2004] and Project Management Maturity Models (PMMM) [Kwak \& lbbs, 2002; Dinsmore \& Cabanis-Brewin, 2005; Crawford, 2006]. The Organisational Project Management Maturity Model (OPM3) [PMI, 2003] was not used as this would make it impossible to compare results with the Prosperus 2003 report.

The researchers performed the necessary preparations to improve their essential competence in the field, which included the clarification of biases and assumptions [LeCompte, Preissle \& Renata, 1993] which should enhance the validity and reliability of the findings.

Merriam's strategies [1999] (peer/colleague examination, the statement of the researcher's biases, submerging the researcher in the study) were followed in this study, thus enhancing the internal validity of the findings.

The following section focuses on the analysis of the data in relation to the factors that contribute to ICT project outcomes in South Africa. 


\section{ICT Project Outcomes}

The interpretation of project success, failure and challenge was left to the discretion of the respondent, as this is still being debated with several opposing views [Turner, 2004; Yu, Flett \& Bowers, 2005; Agarwal \& Rathod, 2006; Wang \& Huang, 2006; Jha \& Iyer, 2007; Shepherd, Covin \& Kuratko, in press].

The first question in the survey focused on the number and outcome of projects managed by respondents. The total number of projects managed by the 206 respondents between 2005 and 2007 was 529. Figure 1 is a graphical representation of the findings and from this it can be seen that according to the respondents, $37 \%$ of ICT projects were perceived as successful, $27 \%$ were perceived as failures and $36 \%$ were challenged.

Figure 1: ICT Project Success Rate

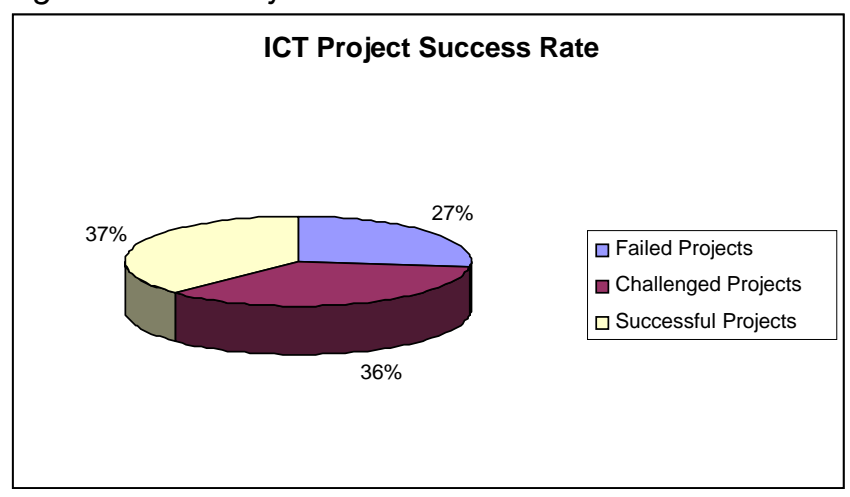

Twenty-seven per cent still represents a significant waste of financial resources, time and effort. Table 1 below shows the longitudinal analysis.

Table 1: Comparison of Project Outcome between Prosperus 2003 and 2007 Survey

\begin{tabular}{|l|l|l|l|}
\hline $\begin{array}{l}\text { Project } \\
\text { Outcome }\end{array}$ & $\begin{array}{l}\text { Prosperus 2003 } \\
\%\end{array}$ & $\begin{array}{l}\mathbf{2 0 0 7} \text { Survey } \\
\%\end{array}$ & $\begin{array}{l}\text { Variation } \\
\%\end{array}$ \\
\hline Failures & 22 & 27 & $\uparrow 5$ \\
\hline Challenged & 35 & 36 & $\uparrow 1$ \\
\hline Successful & 43 & 37 & $\downarrow 6$ \\
\hline
\end{tabular}

These results show that challenged projects have remained the same, while failures have increased and successes have decreased. Given the development and maturation of project management as a discipline, the expectation would have been the opposite, i.e. to see an increase in successful projects and a decrease in failures.

This indicates that there has been a change in the practices, the way outcome is measured and/or the characteristics of the projects being undertaken. Further investigation is required to determine the exact reasons for this phenomenon.

Based on the fact that a significant portion of ICT projects in South Africa are perceived as failures, the following section focuses on the correlation between project size and project outcome. Ives [2005] states that ICT projects fail because of the project's size, which is often of a greater magnitude than originally perceived. The Chaos chronicles also support the causality of project size on project outcome [Hyväri, 2006].

\section{Relationship between Project Size and Project Outcome}

The second question in the survey follows on from the previous section and focuses on the factors that influence project outcome. The focus was on the last project that a respondent was involved in, 
with the first determinant being size. Respondents were given four qualitative sizes without any limiting quantifiers.

The first part focused on the size of the last failed project and was based on a total of 143 projects. Sixty-three respondents stated that they had never been involved in a failed project. The results are shown in figure 2.

Figure 2: Size of last failed project

\section{Size of Last Failed Project}
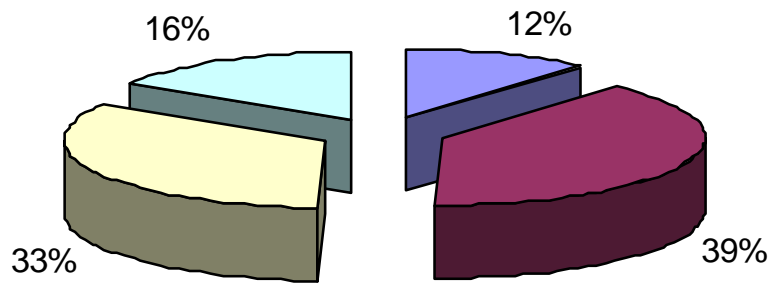

$\square$ Very Small

$\square$ Small

$\square$ Large

$\square$ Very Large

The results indicate a normal distribution with a cumulative total of $72 \%$ for small $(39 \%)$ and large (33\%) projects.

The second part focused on the impact the project size had on challenged projects and was based on a total of 187 projects. Nineteen respondents indicated that they had not been involved in a challenged project before. The results are displayed in figure 3.

Figure 3: Size of last challenged project

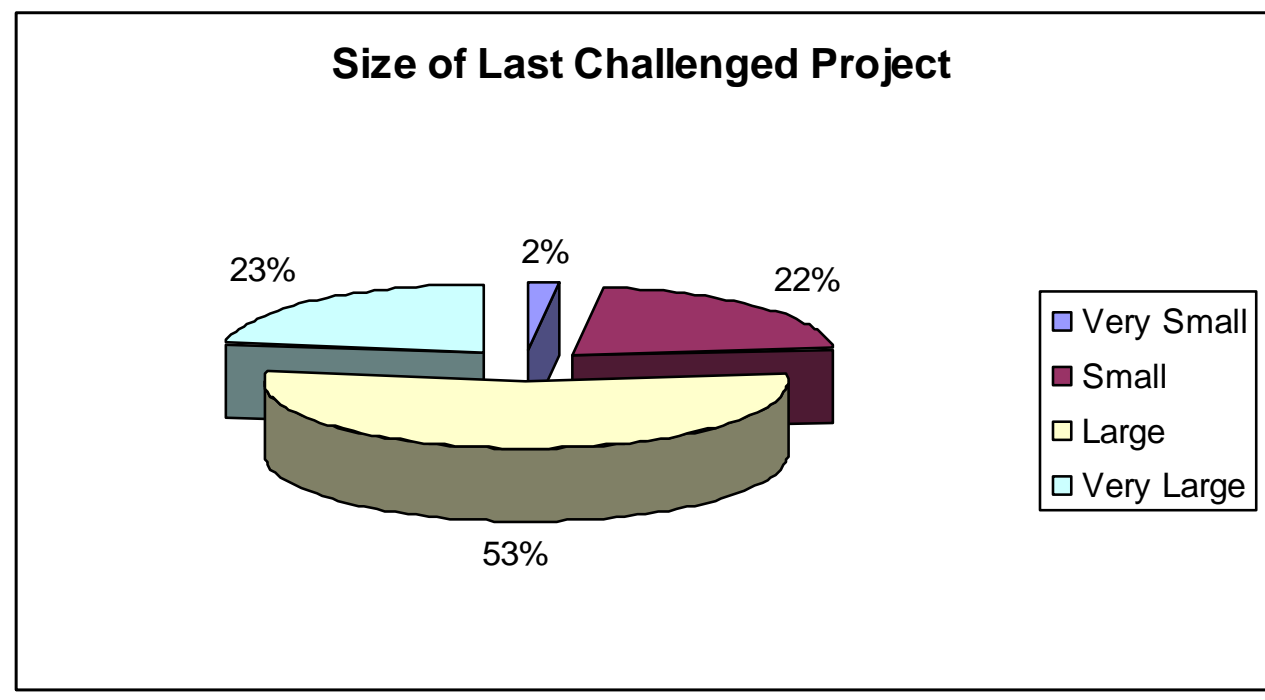

The results are similar to the previous part as a cumulative total of $75 \%$ is shown for small (22\%) and large $(53 \%)$ projects. The major difference is that a significantly larger part of very large projects $(23 \%)$ was perceived as challenged compared to a significantly smaller portion of very small $(2 \%)$ projects. 
The third part focused on the relationship between project size and successful projects and was based on a total of 199 projects. Seven respondents indicated that they had not been involved in a successful project before. The results are displayed in figure 4.

Figure 4: Size of last successful project

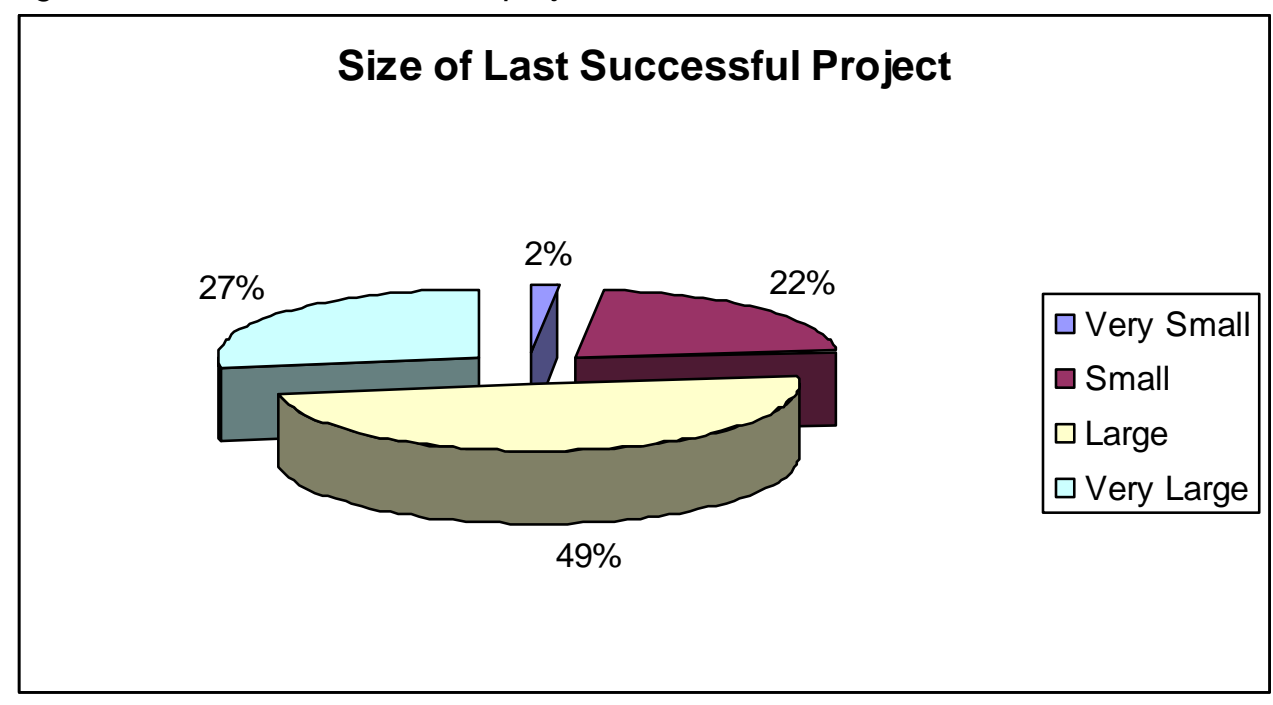

Again, the results are very similar to the previous parts as a cumulative total of $71 \%$ is shown for small $(22 \%)$ and large $(49 \%)$ projects. The results are similar to the challenged projects in that a significantly larger part of very large projects $(27 \%)$ was perceived as successful compared to a significantly smaller portion of very small $(2 \%)$ projects. Table 2 below shows a summary of the above results.

Table 2: Project size in relation to project outcome

\begin{tabular}{|l|l|l|l|l|l|l|}
\hline & $\begin{array}{l}\text { Total } \\
\text { Number } \\
\text { of } \\
\text { Projects }\end{array}$ & $\begin{array}{l}\text { Very } \\
\text { Small }\end{array}$ & Small & Large & $\begin{array}{l}\text { Very } \\
\text { Large }\end{array}$ & TOTAL \\
\hline $\begin{array}{l}\text { What was the size of your last } \\
\text { failed project? }\end{array}$ & 143 & $12 \%$ & $39 \%$ & $33 \%$ & $16 \%$ & $\mathbf{1 0 0 \%}$ \\
\hline $\begin{array}{l}\text { What was the size of your last } \\
\text { challenged project? }\end{array}$ & 187 & $2 \%$ & $22 \%$ & $53 \%$ & $23 \%$ & $\mathbf{1 0 0} \%$ \\
\hline $\begin{array}{l}\text { What was the size of your last } \\
\text { successful project? }\end{array}$ & 199 & $2 \%$ & $22 \%$ & $49 \%$ & $27 \%$ & $\mathbf{1 0 0} \%$ \\
\hline
\end{tabular}

Given the information in table 2, it can be reasoned that the larger the project, the higher the potential for the project to be a success or challenged. Very small projects have a greater relative probability of failure $(12 \%)$ compared to success $(2 \%)$, and for small projects this figure is $39 \%$ and $22 \%$, respectively. Very large projects, on the other hand, have a better chance of success: $27 \%$ compared to $16 \%$ failing; and for large projects the results are $49 \%$ and $33 \%$, respectively.

Figure 5 is a graphical presentation of the project size in relation to the project success. It is clear that the distribution of the failed projects is fairly normal, but the distribution of challenged and successful projects is skewed towards the large and very large projects. 
Figure 5: Project size in relation to project outcome

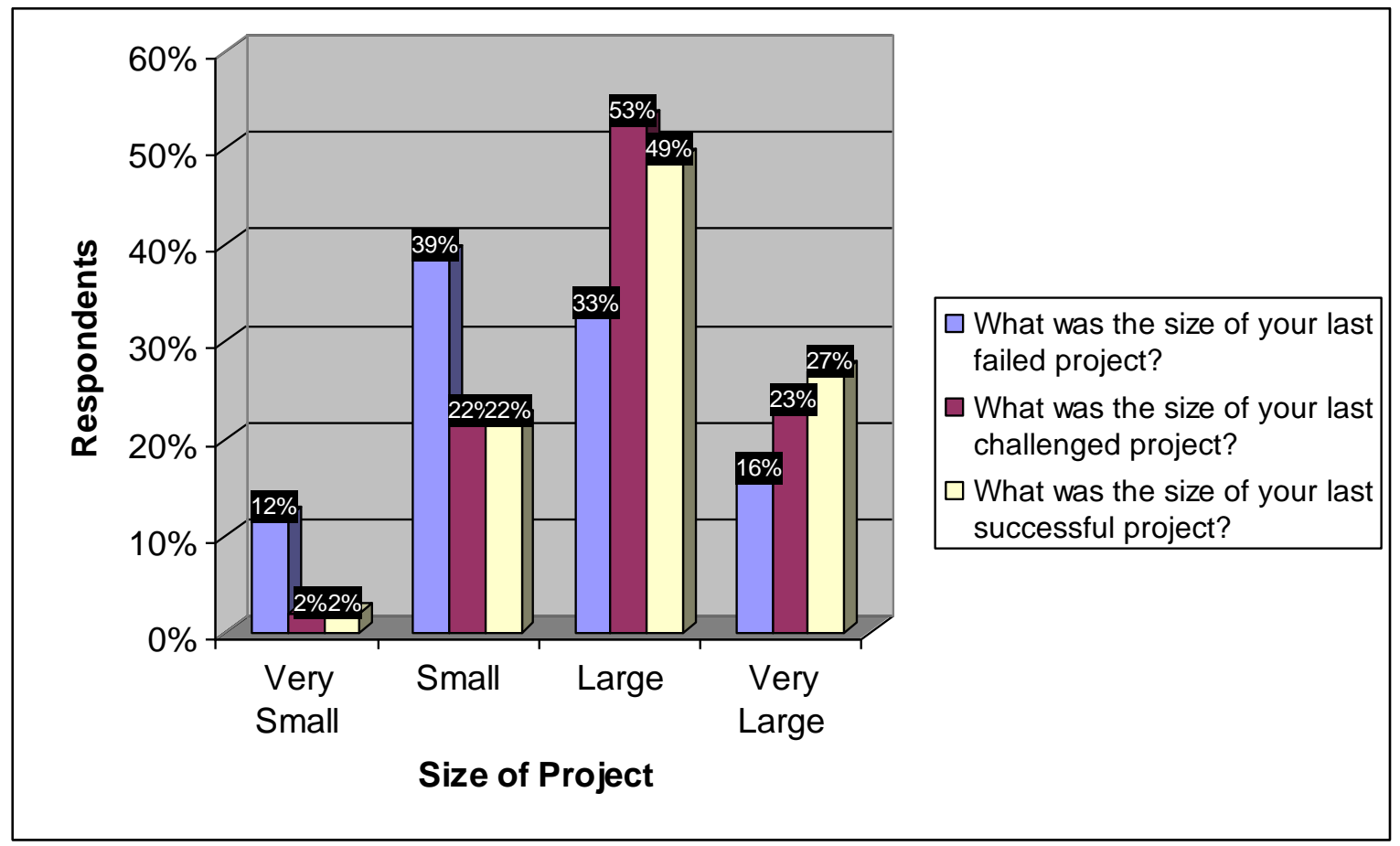

The final section of the article focuses on the factors that influence the outcome of the project: successful, challenged or failed.

\section{Factors Influencing Project Outcome}

The respondents were asked to indicate the factors that made a direct contribution to the outcome of the project. Respondents were only asked if a factor influenced the outcome of the project and not to rate them relative to one another. The factors were compiled from what was used in the Chaos chronicles [Jugdev \& Müller, 2005] as well as an intensive literature review [Nguyen, Ogunlana \& Lan, 2004; Andersen, Birchall, Jessen \& Money, 2006; Ali, Anbari \& Money, 2008]. Table 3 shows the factors for each outcome with the top three scores for each category highlighted.

Table 3: Factors influencing project outcome

\begin{tabular}{|l|l|l|l|}
\hline Factors Influencing Project Outcome & $\begin{array}{l}\text { Failed } \\
\text { Projects }\end{array}$ & $\begin{array}{l}\text { Challenged } \\
\text { Projects }\end{array}$ & $\begin{array}{l}\text { Successful } \\
\text { Projects }\end{array}$ \\
\hline Communication between team \& customers & 47 & 54 & 156 \\
\hline Executive support & 47 & 36 & 121 \\
\hline Handling of change & 45 & 52 & 110 \\
\hline User involvement & 45 & 45 & 104 \\
\hline Clarity of business objectives & 39 & 55 & 133 \\
\hline Clarity of requirement definition & 37 & 56 & 126 \\
\hline User understanding of technology & 36 & 50 & 75 \\
\hline Change control processes & 36 & 27 & 85 \\
\hline Understanding of user's needs & 30 & 37 & 115 \\
\hline Communication between project team members & 26 & 40 & 150 \\
\hline Formal methodologies & 26 & 30 & 87 \\
\hline Project manager competency & 22 & 28 & 121 \\
\hline Support of innovative technology & 20 & 21 & 64 \\
\hline
\end{tabular}




\section{Auditing of processes}

16

27

45

It is apparent from the above table that respondents were more confident in terms of the factors and their influence on successful projects than on their influence on failed projects.

Based on the information in table 3, the two main themes of the top four factors for failed projects are people (communication between team and customers; executive support; user involvement) and processes (dealing with change). Various literature sources support this finding [Van Marrewijk, 2007; Nieminen \& Lehtonen, 2008; Bellini \& Canonico, 2008].

For challenged projects, two main themes emerge, namely people (communication between team members) and direction (clarity of business objectives; clarity of requirement definition). For successful projects, two main themes also emerge, namely people (communication between team and customers; communication between project team members) and direction (clarity of business objectives; clarity of requirement definition). Figure 6 shows the different themes and how these themes relate to project outcome.

\section{Figure 6: Relationship between themes and project outcome}

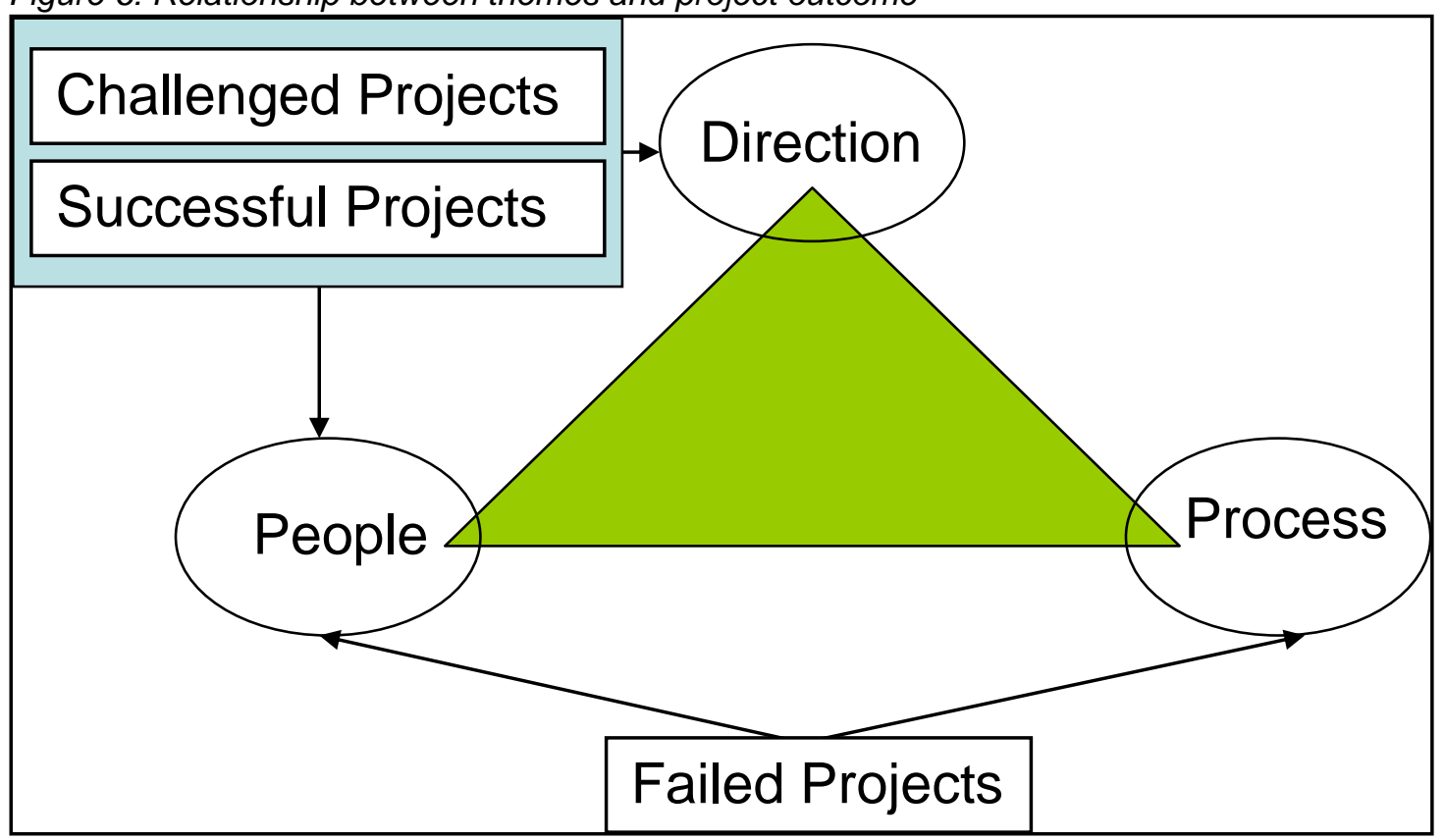

The only common factor across all three project outcomes is communication between team and customers. Communication on projects has long been recognised as a critical success factor for project success [Goczol \& Scoubeau, 2003; Chiocchio, 2007; Peterson, 2007]. Good communication facilitates project success while poor communication hinders it.

When analysing the commonality between challenged and successful projects, two factors emerge. These are communication between team and customers and clarity of business objectives, often defined by the customer. This clearly shows the importance of a collaborative approach between project team and customer, as well as the importance of aligning projects with business objectives. Misaligned projects are often perceived as failures despite being completed within the triple constraints. Aligned projects, although sometimes being over budget or schedule, are often perceived as successful as they still deliver some degree of business value which is, from a business perspective, more important than adherence to the triple constraint. Based on the above finding, a number of recommendations can be made to improve the probability of project success. 


\section{RECOMMENDATIONS}

From the above findings, the following recommendations are made:

- Organisations must provide clear guidance on how to measure the outcome of an ICT project. Several references can assist an organisation in developing such criteria [Bryde, 2003; Olsson, Johansen, Langlo \& Torp, 2008].

- Small projects should not be underestimated. The same effort and focus must be applied to the management of small projects as to large projects. Several formal methodologies have been developed that focus on the management of small projects [Ken, 1994; Rowe, 2007].

- Alignment between business objectives and projects is crucial. Poor alignment can lead to wasted effort and resources despite completing a project within the triple constraints. There are several methods for ensuring alignment [Marnewick \& Labuschagne, 2006; Marnewick \& Labuschagne, 2008].

- A good relationship between customer and project team is fundamental to project success. Projects require a collaborative environment and not an adversarial one. Several publications are available on establishing and maintaining such an environment [Stewart, 2001; Bourne \& Walker, 2006].

\section{CONCLUSION}

The focus of the article is to develop a better understanding of current practices in ICT projects in South Africa. The first section illustrated the current state of ICT project outcomes. The second and third sections showed the correlation between project size and outcome as well as the factors that influence the outcome of an ICT project.

As can be seen from the above results, the outcome of ICT projects in South Africa has changed over the last few years. An increase in the maturity of the project management discipline does not necessarily mean that more projects are managed successfully. The factors that contribute to a successful outcome are often outside the direct control of the project manager and tend to be complex in nature. The second conclusion is that project size could influence the outcome. Further investigation is required to determine why small projects tend to be more likely to fail than to succeed. The final conclusion is that the alignment of projects with business objectives influences their perceived success.

The value of the research results presented in this paper lies in the realisation that project success is not just determined by adherence to best practices or formal processes, but requires an environment and context conducive to business success. Project success cannot be viewed in isolation either. The cumulative result of projects is what ultimately determines business success.

Since this research is longitudinal, the research will continue to determine if there are any improvements in the successful delivery of ICT projects and what organisations must have in place to ensure continuous improvement.

\section{REFERENCES}

Agarwal, N. \& Rathod, U. 2006. Defining 'success' for software projects: an explanatory revelation. International Journal of Project Management, 24:358-70.

Ahlemann, F., Teuteberg, F. \& Vogelsang, K. In press. Project management standards - diffusion and application in Germany and Switzerland. International Journal of Project Management.

Ali, A.S.B., Anbari, F.T. \& Money, W.H. 2008. Impact of organisational and project factors on acceptance and usage of project management software and perceived project success. Project Management Journal, 39(2):5-34.

Andersen, E.S., Birchall, D., Jessen, S.A. \& Money, A.H. 2006. Exploring project success. Baltic Journal of Management, 1(2). 
Armstrong, B. \& Everett, J. 1990. Research Note: Book/Software Review: SPSS for teaching statistics in marketing. Asia Pacific Journal of Marketing and Logistics, 2(1).

Bellini, E. \& Canonico, P. 2008. Knowing communities in project driven organizations: analysing the strategic impact of socially constructed HRM practices. International Journal of Project Management, 26:44-50.

Blanche, M.T. \& Durrheim, K. 2004. Research in practice. Cape Town: UCT Press.

Bless, C. \& Higson-Smith, C. 2004. Fundamentals of social research methods. Cape Town: Juta Education.

Bourne, L. \& Walker, D.H.T. 2006. Visualizing stakeholder influence - two Australian examples. Project Management Journal, 37(1):5-22.

Bryde, D.J. 2003. Modelling project management performance. International Journal of Quality \& Reliability Management, 20(2).

Chiocchio, F. 2007. Project team performance: a study of electronic task and coordination communication. Project Management Journal, 38(1):97-110.

Crawford, J.K. 2006. Project management maturity model. CRC Press.

Crawford, L. \& Pollack, J. 2007. How generic are project management knowledge and practice? Project Management Journal, 38(1):87-96.

Crawford, L., Pollack, J. \& England, D. 2007. How standards are standards: an examination of language emphasis in project management standards. Project Management Journal, 38(3):6-22.

Creswell, J.W. 2003. Research design: qualitative, quantitative, and mixed method. London: Sage.

Devlin, A.S. 2006. Research methods: planning, conducting and presenting research. Australia: Thomson/Wadsworth.

Dinsmore, P.C. \& Cabanis-Brewin, J. 2005. The AMA handbook of project management. 2nd edition. Amacom.

Emrouznejad, A., Parker, B.R. \& Tavares, G. 2008. Evaluation of research in efficiency and productivity: a survey and analysis of the first 30 years of scholarly literature in DEA. SocioEconomic Planning Sciences, 42(3):151-157.

Goczol, J. \& Scoubeau, C. 2003. Corporate communication and strategy in the field of projects. Corporate Communications: An International Journal, 8(1).

Hart, S.J. 1989. Collection and analysis of interview data. Marketing Intelligence and Planning, 7(5/6).

Hinton, P.R., Brownlow, C. \& McMurray, I. 2004. SPSS explained. London: Routledge.

Hyväri, I. 2006. Success of projects in different organizational conditions. Project Management Journal, 37:31.

Ives, M. 2005. Identifying the contextual elements of project management within organizations and their impact on project success. Project Management Journal, 36(1):37-51.

Jha, K.N. \& lyer, K.C. 2007. Commitment, coordination, competence and the iron triangle. International Journal of Project Management, 25:527-540.

Jugdev, K. \& Müller, R. 2005. A retrospective look at our evolving understanding of project success. Project Management Journal, 36(4):19-31.

Ken, B. 1994. Managing small projects in a PRINCE environment. Oxford: NCC Blackwell.

Kwak, Y.H. \& lbbs, C.W. 2002. Project management process maturity (PM)2 model. Journal of Management in Engineering, 18(3):150-156.

LeCompte, M.D., Preissle, J. \& Renata, T. 1993. Ethnography and qualitative design in education research. San Diego: Academic Press. 
Leeper, J.D. n.d. Choosing the correct statistical test in SAS, Stata \& SPSS. Available from http://www.ats.ucla.edu/stat/mult_pkg/whatstat/default.htm (Accessed 30 July 2008).

Leyborne, S.A. 2007. The changing bias of project management research: a consideration of the literatures and an application of extant theory. Project Management Journal, 38(1):61-74.

Marnewick, C. \& Labuschagne, L. 2006. A structured approach to derive projects from the organisational vision. Conference proceedings of the PMI Research Conference 2006. Montreal: Project Management International.

Marnewick, C. \& Labuschagne, L. 2008. The substantiation of the vision-to-project (V2P) framework through action research. Conference proceedings of the PMI Research Conference 2008. Warsaw: Project Management International.

McPherson, C. n.d. Challenged projects: Thoughts for building the plane while it is flying. Available from http://www.pmi-thumbchapter.org/Presentation_2003-04-08.pdf (Accessed 8 April 2008).

Merriam, S.B. 1999. Case study research in education: a qualitative approach. San Francisco: Jossey-Bass.

Muller, R. \& Turner, R. 2007. The influence of project managers on project success criteria and project success by type of project. International Journal of Project Management, 25(4):298-309.

Nieminen, A. \& Lehtonen, M. 2008. Organisational control in programme teams: an empirical study in change programme context. International Journal of Project Management, 26:63:72.

Nguyen, L.D., Ogunlana, S.O. \& Lan, D.T.X. 2004. A study on project success factors in large construction projects in Vietnam. Engineering, Construction and Architectural Management, 11(6).

O'Leary, T. \& Williams, T. 2008. Making a difference? Evaluating an innovative approach to the project management centre of excellence in a UJ government department. International Journal of Project Management, 26(5):556-565.

Olsson, N.O.E., Johansen, A., Langlo, J.A. \& Torp, O. 2008. Project ownership: implications on success measurement. Measuring Business Excellence, 12(1).

Page, C. \& Meyer, D. 2000. Applied research design for business and management. Sydney: McGraw-Hill.

Patton, M.Q. 2002. Qualitative research and evaluation methods. London: Sage.

Pellegrinelli, S., Partington, D., Hemingway, C., Mohdzain, Z. \& Shah, M. 2007. The importance of context in programme management: an empirical review of programme practices. International Journal of Project Management, 25:41-55.

Peterson, T.M. 2007. Motivation: how to increase project team success performance. Project Management Journal, 38(4):60-70.

PMI. 2003. Organizational project management maturity model (OPM3). Pennsylvania: Project Management Institute.

[PMI. 2004. The guide to the project management body of knowledge. Pennsylvania: Project Management Institute.

Rowe, S.F. 2007. Project management for small projects. Vienna, VA: Management Concepts.

Rubinstein, D. 2007. Standish Group Report: There's less development chaos today. Software Development Times.

Sewchurran, K. \& Barron, M. 2008. A systemic enquiry to learn about the project manager-project sponsor relationship. Conference proceedings of the PMI Research Conference 2008. Warsaw: Project Management International.

Schwalbe, K. 2007. Information technology project management. 5th edition. USA: Thomson Course Technology. 
Shepherd, D.A., Covin, J.G. \& Kuratko, D.F. In press. Project failure from corporate entrepreneurship: managing the grief process. International Journal of Project Management.

Smith, A.D. 2003. Surveying practicing project managers on curricular aspects of project management programs: a resource-based approach. Project Management Journal, 34(2):26-32.

So, A.T.P. \& Leung, A.Y.T. 2004. Survey on attitudes towards buildings in three Chinese cities: Hong Kong, Shanghai and Taipei. Facilities, 22(3/4).

Sonnekus, R. \& Labuschagne, L. 2003. The Prosperus Report 2003: ICT project management maturity versus project success in South Africa. Johannesburg: Rand Afrikaans University.

Sonnekus, R. \& Labuschagne, L. 2004. Establishing the relationship between ICT project management maturity and ICT project success in a South African context. 2004 PMSA International Conference. Johannesburg: PMSA.

Stewart, W.E. 2001. Balanced scorecard for projects. Project Management Journal, 32(1):38-54.

Thomas, G. \& Fernandez, W. In press. Success in ICT projects: a matter of definition? International Journal of Project Management.

Turner, R.J. 2004. Five necessary conditions for project success. International Journal of Project Management, 22:349-350.

Van Marrewijk, A. 2007. Managing project culture: the case of Environ Megaproject. International Journal of Project Management, 25:290-299.

Wang, X. \& Huang, J. 2006. The relationships between key stakeholders' project performance and project success: perceptions of Chinese construction supervising engineers. International Journal of Project Management, 24:253-260.

Yu, A.G., Flett, P.D. \& Bowers, J.A. 2005. Developing a value-centred proposal for assessing project success. International Journal of Project Management, 23:428-436. 